Chirurgia (2021) 116: 193-200

No. 2, March - April

Copyright@ Celsius

http://dx.doi.org/10.21614/chirurgia.116.2.193

\title{
Surgical Features after Neoadjuvant Treatment for Breast Cancer
}

\author{
Emil Popa', Adrian Croitoru', Daniel Cristian', Nicolae Jitea', Razvan Scaunasu', Ciprian Aldea², lleana Popa ${ }^{3}$, \\ Traean Burcos ${ }^{1 *}$
}

1Department of Surgery, Coltea Hospital, Bucharest, Romania

${ }^{2}$ Department of Oncology, Coltea Hospital, Bucharest, Romania

${ }^{3}$ Department of Pathology, Coltea Hospital, Bucharest, Romania

${ }^{*}$ Corresponding author:

Professor Traean Burcos

Department of Surgery

Coltea Hospital, Bucharest, Romania

E-mail: traeanburcos@yahoo.com

\section{Rezumat \\ Considerații chirurgicale după tratamentul neoadjuvant pentru cancer de sân}

Introducere: Pacienții cu neoplasm mamar pot primi tratament oncologic neoadjuvant pentru a putea beneficia de intevenții chirurgicale radicale sau pentru a transforma o indicatie de intervenție chirurgicala amplă într-o intervenție conservatoare sau oncoplastică.

Material şi Metodă:Sunt analizate 35 de paciente cu cancer de sân operate în anul 2020, post tratament neoadjuvant, în Clinica de Chirurgie a Spitalului Colțea iar răspunsul post tratament este evaluat pe piesa de rezecție chirurgicală folosind metoda RCB (Residual Cancer Burden).

Rezultate: Analiza lotului de pacienți arată că majoritatea pacientelor au prezentat o scădere a stadiului bolii ca urmare a tratamentului oncologic neoadjuvant, cu o proporție de $17,14 \% \mathrm{cu}$ răspuns patologic complet

Discutii: Am evaluat clinic şi imagistic pacientele din lotul de studiu înainte şi după tratamentul neoadjuvant şi am evaluat anatomo-patologic piesele de rezecție chirurgicală folosind metoda Residual Cancer Burden, luând în calcul în acelaşi timp vârsta pacientelor, stadializarea clinică şi anatomo-patologică, statusul receptorilor hormonali şi statusul Her 2.

Concluzii: Chimioterapia neoadjuvantă face parte din arsenalul terapeutic al cancerului de sân, fiind urmată în majoritatea cazurilor de scăderea stadiului tumoral şi creşterea numărului de tumori operabile. $17.1 \%$ din cazurile studiate au avut răspuns 
patologic complet, 2 dintre acestea fiind Her 2 pozitive. Tratamentul neoadjuvant poate duce la o creştere a numărului de paciente care pot beneficia de intervenții chirurgicale conservatoare şi oncoplastice.

Cuvinte cheie: terapie neoadjuvantă în cancerul de sân, răspuns patologic complet, chirurgie conservatoare a cancerului de sân

\begin{abstract}
Introduction: Patients with breast cancer may receive neoadjuvant cancer treatment in order to benefit from radical surgery or to turn an indication for extensive surgery into a conservatory or oncoplastic operation. Aim: To establish the main implications of therapeutic management of the cases of breast cancer treated initially with chemotherapy followed by surgery.

Material and Method: 35 breast cancer patients operated in 2020 after NACT (neoadjuvant chemotherapy) in Surgery Clinic of Coltea Hospital are analyzed, and the response after treatment is pathologicaly evaluated using the Residual Cancer Burden method

Results: The results of the analysis of the group of patients showed that most patients presented downstaging of the disease after neoadjuvant treatment with a proportion of $17,14 \%$ with complete pathologic response.

Discussions: We performed clinical and imagistic evaluation of patients before and after NACT and pathologic evaluation of the surgical specimen using residual tumor burden method, taking into account the age of the patients, clinical and pathological staging and the status of hormone receptors and Her 2.

Conclusions: Neoadjuvant chemotherapy is currently part of the therapeutic arsenal of breast cancer being followed in most cases by downstaging of tumors and increasing the number of cases that can be operated. $17.1 \%$ of cases achieved pathologic complete response, 2 of them being Her 2 positive carcinomas. The use of conservative and oncoplastic surgical techniques is possible after downstaging tumors by NACT.
\end{abstract}

Key words: neoadjuvant therapy in breast cancer, complete pathological response, conservative breast cancer surgery

\section{Introduction}

Neoadjuvant chemotherapy (NACT) can be defined as the oncologic treatment performed to patients with local or locally advanced disease prior to surgery. There are many potential benefits of preoperative systemic therapy: it may increase the number of cases in which conservative surgery can be applied, it can make operable malignant breast tumors that are initially inoperable at diagnosis, provides important prognostic information based on response to therapy, especially in patients with triple negative or Her2 positive tumors
$(1,2)$. For patients with HER 2 positive disease neoadjuvant chemotherapy plus Her 2 dual blocade (Transtuzumab + Pertuzumb) provide a rate of $\sim 60 \%$ pathologic complete response. That translate in a better overall survival. On the other hand, neoadjuvant chemotherapy offers the possibility to modify adjuvant systemic therapy regimens in patients with residual disease It also makes possible to reduce the fields of adjuvant radiotherapy or even to avoid radiotherapy in case of axillary negative lymph nodes or in case of obtaining complete pathological response. It is very important that NACT may allow sentinel node 
biopsy (SLNB) as an axillary approach technique if the regional lymph nodes are negative after treatment and provides time for planning breast reconstruction. Also, NACT is an excellent research platform to test new therapies and new predictive biomarkers.

Which patients would benefit from neoadjuvant chemotherapy? Patients with inoperable breast cancer should be considered first, with the desire to turn them into operable cases: patients with inflammatory breast cancer, those with large, fixed, N3 lymph nodes or with $\mathrm{T} 4$ tumors. In addition, neoadjuvant chemotherapy should be given to patients in whom the following outcomes may be achieved: subjects with large breast tumor compared to the breast, who opt for breast preservation, in order to decrease the size of the tumor and improve the ratio with the remaining breast tissue, when lymph node disease is likely to respond to systemic therapy, or if it takes time to decide on surgical options. Other situations are that of patients with high risk Her2-positive or triple negative disease and patients in which we need time to decide about surgical options (3).

In general, after neoadjuvant treatment we expect to be able to operate on patients who were initially inoperable and to be able to perform conservative or oncoplastic interventions on patients for whom we would initially have indicated only mammectomy.

\section{Aim}

For surgeons, the general main objective in breast surgery remains the excision of the neoplastic tissue completely, radical resection, R0. The second important objective of the surgical procedure, is the attempt to reduce the number of mammectomies in favor of conservative and oncoplastic interventions. Neoadjuvant chemotherapy in many breast cancer patients seems to be useful and we considered necessary to study the following problems $(4,5)$ :

- What is the impact of this problem in the Surgical Clinic of ourhospital?

- How can we evaluate the response to the treatment done before surgery and establish its efficiency?

- What are the criteria according to which we can determine the type of surgical resection after neoadjuvant chemotherapy?

- What is the optimal time interval between the completion of neoadjuvant chemotherapy and the operative moment?

- Which are the main general implications of therapeutic management of the cases of breast cancer treated initially with chemotherapy?

\section{Matherial and Method}

During the year 2020, the number of breast cancer patients operated in the Surgery Clinic of Coltea Hospital was lower than in previous years due to the SARSCOV2 virus pandemic. Thus, only 76 patients were operated for breast cancer. For 35 of these patients (46.6\%), the surgery was performed after neoadjuvant chemotherapy.

The distribution of patients by age groups is presented in Fig. 1. There is a preponderance of patients in the group 55-64 years (31.4\%) and $65-74(31.4 \%)$ followed by groups $45-54(17.1 \%)$ and $35-44(14.2 \%)$. The least affected age groups are those over $85(0)$ and under $34(0)$.

Most of these patients were considered stage IIIB (54.2\%) and stage IIIA (28.5\%), as seen in the diagram in the Fig. 2.

Neoadjuvant chemotherapy was administered following NCCN guidelines. In HER-2 negative cases, regimens of Doxorubicin, Cyclophosphamide (4 cycles every 3 or 4 weeks) followed by Paclitaxel (4 cycles every 3

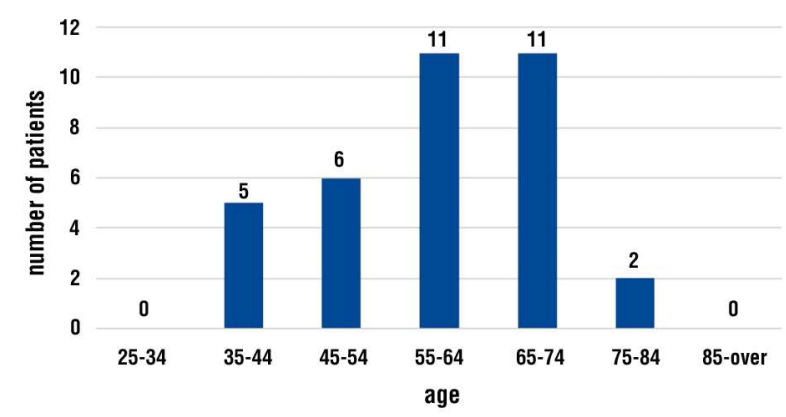

Figure 1. The distribution of number of patients by age 


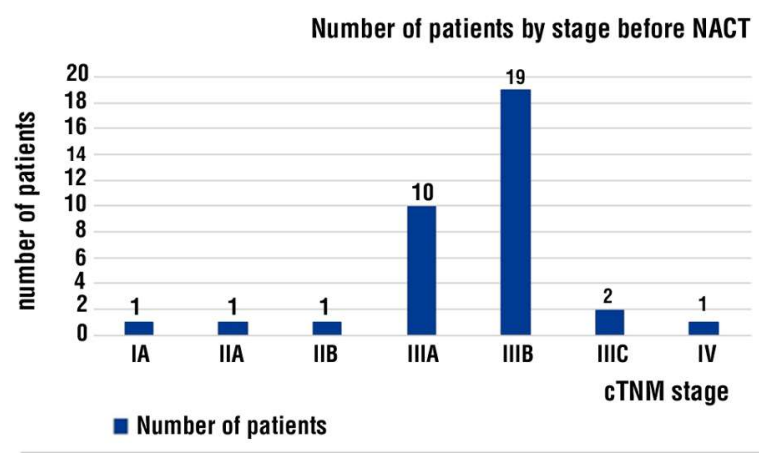

Figure 2. Staging of breast cancer patients who received neoadjuvant chemotherapy and then underwent surgery in 2020

weeks or 12 doses weekly) depending on the tolerance of the treatment. In Her-2 positive patients the same chemotherapy regime were used, the taxane regimes in combination in combination with Her2 blockade with Transtuzumab (recently with dual blockade with Transtuzumab and Pertuzumab. Estrogen - progesterone positive patients, not eligible for chemotherapy, received specific hormone treatment associated with neoadjuvant chemotherapy before surgery.

All patients were examined and staged according to current guidelines, using clinical and imaging methods: mammography, ultrasound, MRI. In all cases, histopathological and immunohistochemical examinations were performed on core needle biopsy samples. The cases were discussed in the multidisciplinary tumor board and neoadjuvant oncological treatment was initiated according to the current NCCN guidelines.

\section{Results}

All patients were monitored for disease response to neoadjuvant treatment using clinical examination and imaging methods (echography, mammography and IRM). All patients were operated by radical interventions (mammectomy and axillary dissection) and the excision specimens were sent to the pathology department to assess the response to neoadjuvant treatment by RCB classification and establish the final pathologic diagnosis.
We considered that the optimal time for surgery is between 2 and 5 weeks and tried to operate in the $5^{\text {th }}$ week after chemotherapy which, for year 2020, was a challenge (6).

In the pathology department, it was performed the gross examination, the specimen was sliced into $5 \mathrm{~mm}$ sections and the cross-section that included the largest pretreatment tumor area was thoroughly sampled. The tumor bed was identified in all cases using clinical and radiologic correlations. We used photos of the specimen and diagrams to identify on the microscopy the area that was sampled and assessing tumor size.

Pre NACT most patients $(57,1 \%)$ from the study group were classified as cT4 using clinical examination, mammography and ultrasonography. After treatment, the number of T4 patients decreased to $3(8,5 \%)$ and the number of patients with $\mathrm{T} 1$ and $\mathrm{T} 2$ tumors increased to $60 \%$. Also we had 8 patients with To and Tis (22,8\%) (Fig. 3).

Pre NACT most patients (60\%) from the study group were classified as cN2. After treatment, the number of $\mathrm{N} 2$ patients decreased to 6 (17.1\%) and the number of patients with No increased from $11.4 \%$ to $40 \%$ (Fig. 4).

From 35 patients treated by NACT and surgery, for 6 patients (17.14\%)- pathologic complete response was achieved. The rest of the patients had residual disease and were evaluated using the Residual Cancer Burden method and clasiffied in three groups (Table 1; Fig. 5).

We also evaluated the patients by pTNM system (Fig. 6).

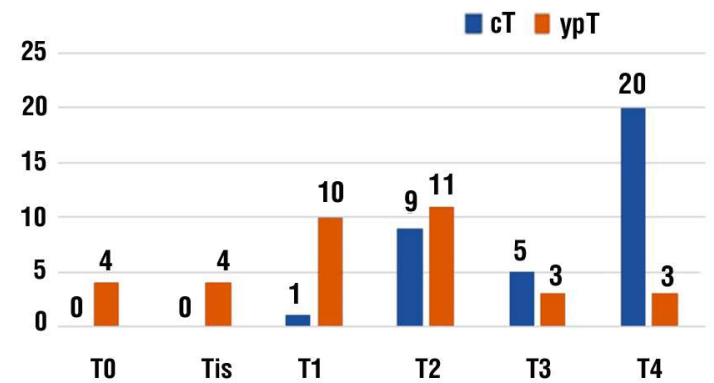

Figure 3. Tumor dimensions pre NACT (CT) and post surgery (ypT) 


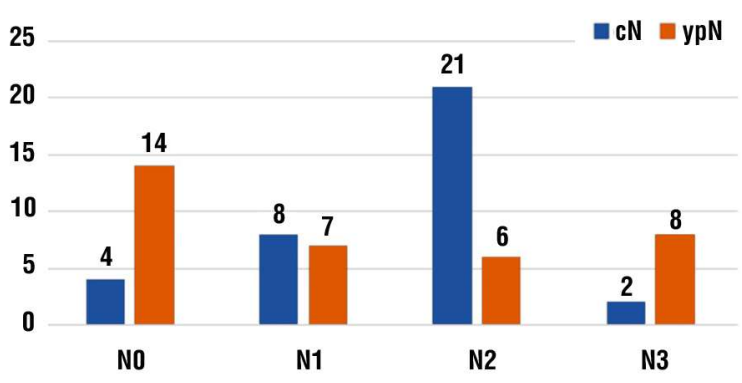

Figure 4. Staging of axilla pre NACT (cN) and post surgery (ypN)

From the 35 cases studied, 33 were ductal invasive carcinomas (invasive NST carcinomas), and 2 of them had mixed patterns including a lobular invasive carcinoma component. Six cases (17.1\%) from the 35 patients in our study were Her 2 positive, 4 hormone receptor positive (11.4\%) and 2 hormone receptor negative (5.7\%). Of these patients, 2 had pathologic complete response after NACT. We had 7 patients with triple negative breast carcinomas and none of them achieved pCR.

\section{Discussions}

The optimal interval between neoadjuvant chemotherapy completion and surgery it is under debate. Post-chemotherapy neutropenia is known to make surgery difficult in the first 3 weeks after NACT and it was found that the rate of complete pathological response is best between 4 and 6 weeks (7). After 6 weeks post NACT increased ki67 levels $(7,8)$, were found. Also, delayed surgery has an increased negative impact on patients' anxiety. We performed surgery for all patients at 5 weeks post NACT.

In all patients we evaluated the tumor post NACT using ultrasonography. Preoperative evaluation of the response to neoadjuvant chemotherapy can be done clinically, using ultrasound, mammography or MRI $(9,10)$. In evaluating the dimensions of the tumor it is considered that the clinical examination has an accuracy of $66 \%$ while the ultrasound has a sensitivity of $75 \%$ and the mammography of 70\% (11-13). Jason D Keune's study published in 2010 in the American Journal of Surgery
Table 1. Number of patients by RCB classes

\begin{tabular}{lcccc}
\hline RCB CLASS & $0(\mathrm{pCR}) \mathrm{T}$ & 1 & 2 & 3 \\
\hline NUMBER OF CASES & 6 & 5 & 11 & 13 \\
\hline
\end{tabular}

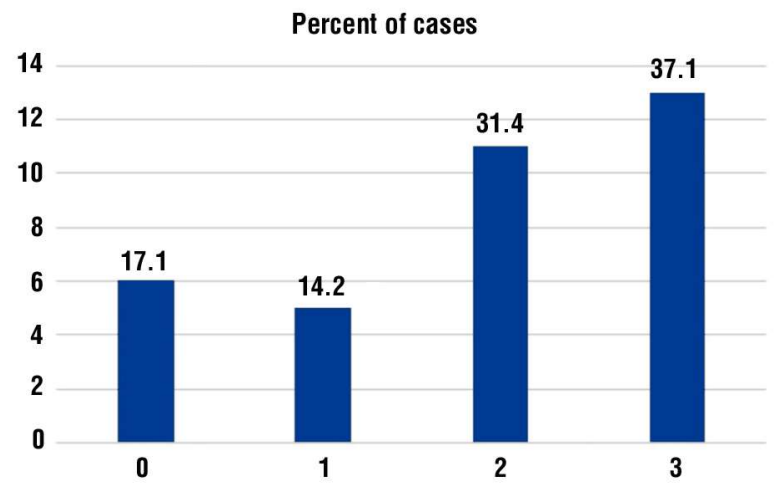

Figure 5. Cases classified by RCB classes

shows that the rate of sensitivity in evaluation the response to chemotherapy can rise for ultrasound to $91.3 \%$ while mammography remains around $60 \%$ (14).

The role of pathologic examination in breast cancer specimens after neoadjuvant therapy is to identify the tumor bed and asses the pathologic response to therapy. Pathological complete response (pCR) as defined by AJCC $8^{\text {th }}$ edition consists of no residual invasive carcinoma in the tumor bed or in the lymph nodes and absence of cancer within blood or lymph vessels (15). It is accepted as pCR the persistence of ductal carcinoma in situ.

Identification of the tumor bed is important for the handling of breast specimens after neoadjuvant therapy. Residual tumor is usually

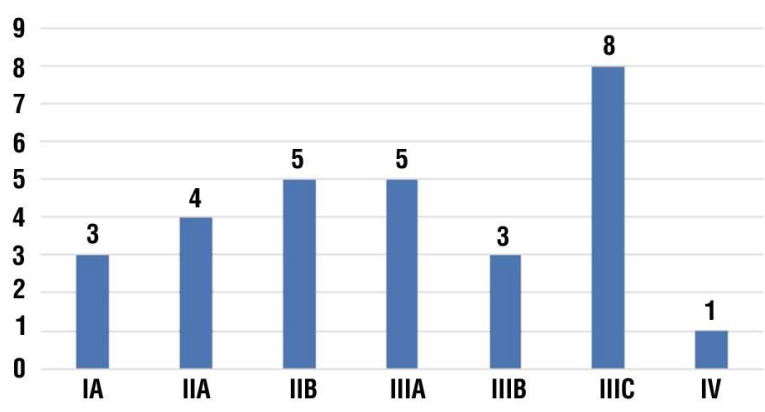

Figure 6. Cases classified by stage after NACT (ypTNM) 
less defined and softer than untreated tumor. If a metallic clip is inserted in the tumor at the moment of the biopsy the identification of the tumor bed is easier, but the clip may shift over time (16). In all our cases, we had to rely on the clinical and radiologic correlations.

After evaluating the tumor size, the next important step is to evaluate the cellularity in the residual tumor. Changes in tumor cellularity after treatment can be heterogeneous and it is necessary to prelevate many tissue fragments from the tumor bed (17); usually there is a decrease in tumor cellularity.

Residual tumor in some cases showed treatment effect with enlarged tumor cells with increased eosinophilic cytoplasm, pleomorphic nuclei and decreased mitotic activity (Fig. 7 ).

Prognostic and predictive factors are the same for all specimens, whether or not they received neoadjuvant treatment before surgery. Some of these factors may be changed by treatment or less reliable but we can compare them with the initial biopsy to assess how neoadjuvant treatment affected histologic architecture, nuclear grade and mitosis.

The recommendation for the reassessment of hormone receptors and HER2 status in residual cancer differs between hospitals with no consensus regarding if and when retesting of markers is adequate. Comparing Ki67 pre and after treatment can help find patients with better long-term outcome (18).

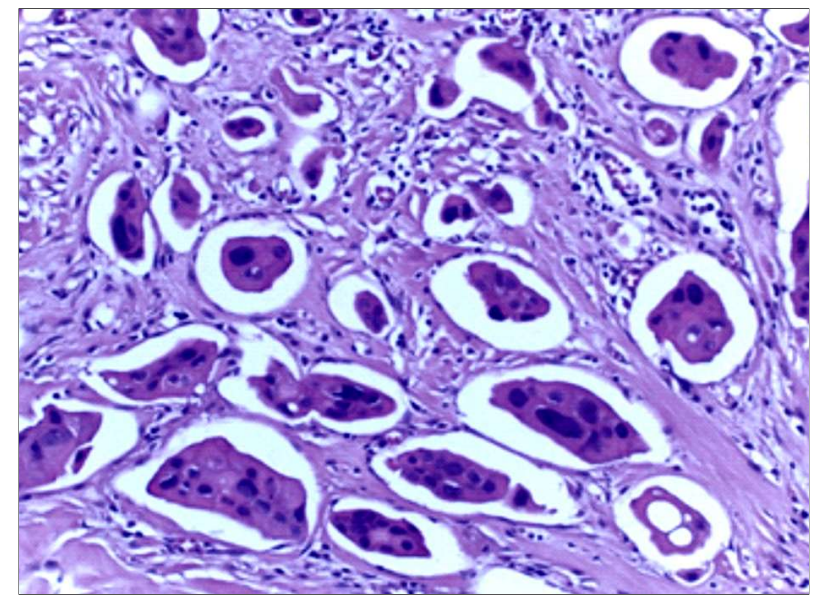

Figure 7. Enlarged tumor cells with eosinophilic cytoplasm and pleomorphic nuclei, col HE, ob 20x
In our study retesting for hormonal status, Her2 and ki67 was done in all cases.

Two of the 6 Her positive cases achieved pCR and all of the 7 triple negative cases had residual disease after NACT.

If residual carcinoma was not present (pCR) we confirmed the identification of the tumor bed microscopically by the presence of hyalinized stroma with granulation tissue, edema, fibroelastosis, foamy histiocytes, cholesterol clefts (Fig. 8).

Lymph node status is the most important prognostic factor in patients who receive neoadjuvant therapy (19). Metastatic lymph nodes with complete response had hyaline stromal scars or areas with foamy histiocytes. Persistent tumor in the axillary lymph nodes is correlated with a worse prognosis, even when a pathological complete response was achieved in the breast (20).

The evaluation of lymph nodes can be done by axillary dissection or by sentinel lymph node technique. Studies suggest that neoadjuvant chemotherapy results in a lower axillary lymph node count (21).

There are several methods for quantifying residual disease. We used The Residual Cancer Burden which is the preferred method in clinical trials in breast cancer. It is simple to apply, it is available online and has been clinically validated with long-term follow-up data.

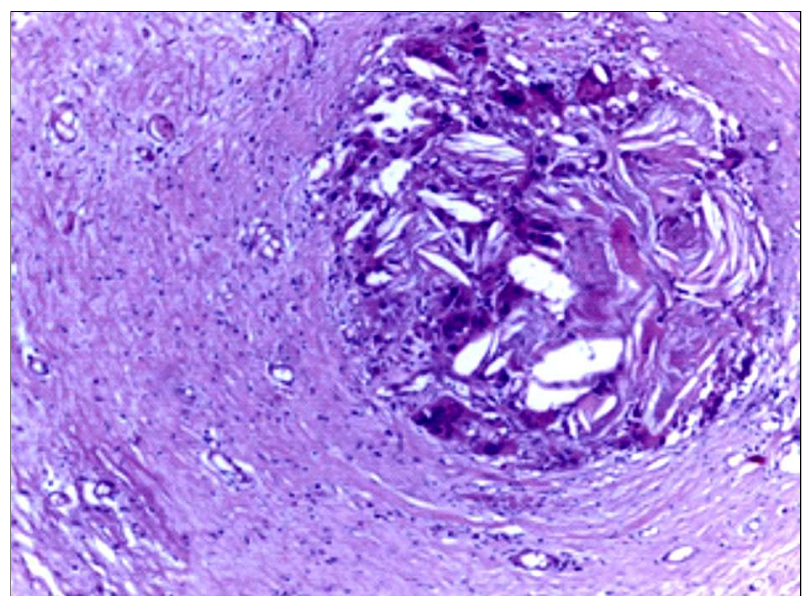

Figure 8. Tumor bed with hyalinized stroma, granulation tissue and cholesterol clefts, col HE, ob 10x 
In conclusion, pathologic evaluation of breast specimens after neoadjuvant therapy is complex and necessitates close correlations with clinical and imagistic findings. Careful review of the specimen is essential for accurate diagnosis and treatment.

In case of a complete response or a partial response of the disease, conservative treatment can be indicated if possible. In the literature the percentage of cases that became treatable by conservative surgery as a result of neoadjuvant treatment is between 15 and $20 \%$ (22). In all cases where mammectomy is performed, reconstruction may be considered (23).

Even in the case of a complete clinical or radiological response, surgical resection is mandatory because there is a weak correlation between clinical/radiological response and pathological complete response. In patients with NACT with potential tumor downstaging, a clip should be placed in the tumor bed. Resection of the entire breast territory initially occupied by the tumor is not mandatory. There is no consensus yet on the size of the uncertain margin, but "no ink on the tumor" is required for microscopic examination and re-excision is considered necessary in the case of the presence of tumor islands on the resection margin. On the other hand, there are no differences in locoregional recurrences between patients with neoadjuvant chemotherapy and those with only adjuvant chemotherapy, but the differences are in terms of the possibility of applying conservative treatment (24).

The use of the sentinel node technique in patients with neoadjuvant chemotherapy is under debate. Discussions revolve around altering lymphatic drainage due to fibrosis secondary to treatment or the presence of tumor emboli.

Regarding the axillary evaluation, NCCN recommends that, in patients treated before surgery, complete axillary lymph dissection should be performed at least levels I and II if there is residual disease at clinical or imaging examination. In these cases of neo-adjuvant treated patients, a sentinel node biopsy may be applied in selected cases with negative lymph nodes at the clinical examination. But among these patients it should be borne in mind that the rate of negative results may be greater than $10 \%(25)$.

\section{Conclusions}

Neoadjuvant chemotherapy is currently part of the therapeutic arsenal of breast cancer being followed in most cases by downstaging of tumors and increasing the number of cases that can be operated. $17,1 \%$ of cases achieved pathologic complete response, 2 of them being Her 2 positive carcinomas. The pathologic complete response is achieved with better overall survival and even cure. The use of conservative and oncoplastic surgical techniques is possible after downstaging tumors by NACT. It is obvious that neoadjuvant treatment is useful and can be adapted to each case during multidisciplinary tumor board meetings - this is how we can talk about personalized medicine, but further studies are needed to reach consensus decisions.

\section{Conflict of Interest}

The authors declare no conflicts of interests.

\section{Ethics Approval}

For performing this study ethical approval was obtained.

\section{References}

1. Morrow M, Khan AJ. Locoregional management after neoadjuvant chemotherapy. J Clin Oncol. 2020;38(20):2281-2289.

2. Korde LA, Somerfield MR, Carey LA, Crews JR, Denduluri N, Shelley Hwang E, et al. Neoadjuvant Chemotherapy, Endocrine Therapy, and Targeted Therapy for Breast Cancer: ASCO Guideline. J Clin Oncol. 2021 Jan 28;JC02003399. doi: 10.1200/JC0.20.03399. Online ahead of print.

3. Liedtke C, Mazouni C, Hess KR, Andre F, Tordai A, Mejia JA, et al. Response to neoadjuvant therapy and long-term survival in patients with triplenegative breast cancer. J Clin Oncol. 2008;26(8):1275-81.

4. Gralow JR, Zujewski JA, Winer E. Preoperative therapy in invasive breast cancer: reviewing the state of the science and exploring new research directions. J Clin Oncol. 2008;26(5):696-7.

5. Kaufmann M, Hortobagyi GN, Goldhirsch A, Scholl S, Makris A, Valagussa $P$, et al. Recommendations from an international expert panel on the use of neoadjuvant (primary) systemic treatment of operable breast cancer: An update. J Clin Oncol. 2006;24(12):1940-9.

6. Tse T, Sehdev S, Seely J, Gravel DH, Clemons M, Cordeiro E, et al. Neoadjuvant Chemotherapy in Breast Cancer: Review of the Evidence and Conditions That Facilitated Its Use during the Global Pandemic. Curr Oncol. 
2021;28(2):1338-1347.

7. Yoo TK, Moon HG, Han W, Noh DY. Time interval of neoadjuvant chemotherapy to surgery in breast cancer: how long is acceptable? Gland Surg. 2017; 6(1):1-3

8. Sanford RA, Lei X, Barcenas CH, Mittendorf EA, Caudle AS, Valero V, et al. Impact of Time from Completion of Neoadjuvant Chemotherapy to Surgery on Survival Outcomes in Breast Cancer Patients. Ann Surg Oncol. 2016;23(5):1515-21.

9. Fowler AM, Mankoff DA, Joe BN. Imaging neoadjuvant therapy response in breast cancer. Radiology. 2017;285(2):358-375.

10. Expert Panel on Breast Imaging: Slanetz PJ, Moy L, Baron P, diFlorio RM, Green ED, Heller SL, et al. ACR Appropriateness Criteria $\circledR^{\circledR}$ Monitoring Response to Neoadjuvant Systemic Therapy for Breast Cancer. J Am Coll Radiol. 2017;14(11S):S462-S475

11. Al-Hilli Z, Boughey JC. The timing of breast and axillary surgery after neoadjuvant chemotherapy for breast cancer. Chin Clin Oncol 2016;5(3):37

12. Stanculeanu DL, Dascalu D, Chivu S, Zob D, Bunghez R. Chimioterapia neoadjuvanta cu Docetaxel, Epirubicina si Cicolfosfamida in cancerul de san. Oncolog-Hematolog.ro, 25 aprilie 2017, Medichub Media.

13. Bordea C, Blidaru A, Voinea S, lanculescu-Oanta V, Plesca M, Condrea I, et al. Identificarea si biopsia ganglionului santinela la pacientele cu neoplasm mamar si chimioterapie neoadjuvanta Congresul National de Oncologie Medicala si Radioterapie Sinaia 18-20 oct 2012. Journal of Radiotherapy and Medical Oncology. 2012;18:29.

14. Keune JD, Jeffe DB, Schootman M, Hoffman A, Gillanders WE, Rebeca L. Accuracy of Ultrasonography and Mammography in Predicting Pathologic Response after Neoadjuvant Chemotherapy for Breast Cancer. Am J Surg. 2010;199 (4):477-484.

15. Amin MB et al (eds). AJCC Cancer Staging Manual, Eighth Edition. DO 10.1007/978-3-319-40618-3 48

16. Park CK, Jung WH, Koo JS. Pathologic Evaluation of Breast Cancer after Neoadjuvant Therapy. J Pathol TransI Med. 2016;50(3):173-180.
17. Provenzano E, Bossuyt V, Viale G, Cameron D, Badve S, Denkert C, et al. Residual Disease Characterization Working Group of the Breast International Group-North American Breast Cancer Group Collaboration. Standardization of pathologic evaluation and reporting of postneoadjuvant specimens in clinical trials of breast cancer: recommendations from an international working group. Mod Pathol. 2015;28(9):1185-201.

18. Hicks M, Macrae ER, Abdel-Rasoul M, Layman R, Friedman S, Querry J, et al. Neoadjuvant dual HER2-targeted therapy with lapatinib and trastuzumab improves pathologic complete response in patients with early stage HER2positive breast cancer: A meta-analysis of randomized prospective clinical trials. Oncologist. 2015; 20(4):337-43.

19. Sunati Sahoo, Susan C Lester. Pathology of breast carcinomas after neoadjuvant chemotherapy: an overview with recommendations on specimen processing and reporting. Arch Pathol Lab Med. 2009;133(4):633-42.

20. Mieog JSD, van der Hage JA, van de Velde CJH. Preoperative chemotherapy for women with operable breast cancer. Cochrane Database Syst Rev. 2007;2007(2):CD005002.

21. Bélanger J, Soucy G, Sidéris L, Leblanc G, Drolet P, Mitchell A, et al. Neoadjuvant chemotherapy in invasive breast cancer results in a lower axillary lymph node count. J Am Coll Surg. 2008;206(4):704-8.

22. Vriens BEPJ, Vriens IJH, Aarts MJB, van Gastel SM, van den Berkmortel FWPJ, Smilde TJ, et al. Improved survival for sequentially as opposed to concurrently delivered neoadjuvant chemotherapy in non-metastatic breast cancer. Breast Cancer Res Treat. 2017;165(3):593-600.

23. https://www.nccn.org/professionals/physician_gls/pdf/breast_blocks.pdf

24. King TA, Morrow M. Surgical issues in patients with breast cancer receiving neoadjuvant chemotherapy. Nat Rev Clin Oncol. 2015;12(6):335-43.

25. Caudle AS, Yang WT, Krishnamurthy S, Mittendorf EA, Black DM, Gilcrease MZ, et al. Improved Axillary Evaluation Following Neoadjuvant Therapy for Patients With Node-Positive Breast Cancer Using Selective Evaluation of Clipped Nodes: Implementation of Targeted Axillary Dissection. J Clin Oncol. 2016;34(10):1072-8 